\title{
Efektivitas Herbisida IPA Glifosat 486 SL Untuk Pengendalian Gulma Pada Budidaya Tanaman Karet (Hevea brasiliensis Muell. Arg) Belum Menghasilkan
}

\author{
Effectiveness of Herbicide Glyphosate IPA 486 SL For Weed Control In Crops Rubber (Hevea \\ brasiliensis Muell. Arg) Immature
}

\section{Gede Supawan, Hariyadi*}

\begin{abstract}
Departemen Agronomi dan Hortikultura, Fakultas Pertanian, Institut Pertanian Bogor (Bogor Agricultural University), Jl. Meranti, Kampus IPB Darmaga, Bogor 16680, Indonesia Telp.\&Faks. 62-251-8629353 e-mail agronipb@indo.net.id

*) Penulis untuk korespondensi : haryadibogor@yahoo.com
\end{abstract}

Disetujui 24 Desember 2013/ Published online 13 Februari 2014

\begin{abstract}
The research was conducted in the plantation PTPN VIII Cikumpay Purwakarta, West Java, from September 2012 unti December 2012. This reaserch was conducted to test the effectiveness of the herbicide glyphosate IPA 486 SL. The experimental design used in this research were randomized design Complete Group (RKLT) with one factor. This research use seven treatments with four replications. Treatment doses

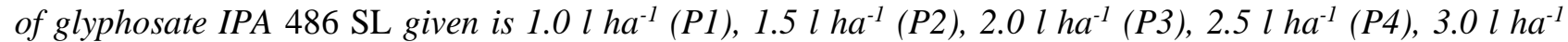
(P5), Weeding Manual (P6), and Control (P7). Herbicide glyphosate IPA 486 SL was not effective in suppressing the growth of weeds in immature rubber plantations.. Calculation the average herbicide treatments at any dose did not show significant differences, although in general there is a decrease in weed dry weight each observation. During observations did not symptoms of poisoning in the rubber plant for each treatment dose. It shows that the application of glyphosate IPA 486 SL herbicide is not dangerous to immature rubber plants.
\end{abstract}

Key words: application, dose, herbicide, glyphosate, weed

\begin{abstract}
ABSTRAK
Penelitian dilakukan di perkebunan PTPN VIII Cikumpay Kabupaten Purwakarta, Jawa Barat, pada bulan September 2012 sampai Desember 2012. Penelitian ini dilakukan untuk menguji efektivitas herbisida IPA glifosat 486 SL. Rancangan percobaan yang digunakan dalam penelitian ini adalah Rancangan Kelompok Lengkap Teracak (RKLT) dengan satu faktor. Penelitian ini menggunakan 7 perlakuan dengan empat ulangan. Perlakuan dosis IPA glifosat $486 \mathrm{SL}$ yang diberikan adalah $1.0 \mathrm{l} \mathrm{ha} \mathrm{h}^{-1}(\mathrm{Pl}), 1.5 \mathrm{l} \mathrm{ha}$ (P2),

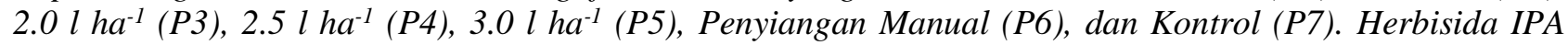
glifosat 486 SL tidak efektif menekan pertumbuhan gulma di perkebunan karet belum menghasilkan. Perhitungan rata-rata perlakuan herbisida pada setiap dosis tidak menunjukan perbedaan yang nyata walaupun secara umum terjadi penurunan berat kering gulma pada setiap perlakuan. Selama pengamatan tidak ditemukan gejala keracunan pada tanaman karet untuk setiap perlakuan dosis. Hal tersebut menunjukan bahwa aplikasi herbisida IPA glifosat 486 SL tidak berbahaya pada tanaman karet belum menghasilkan.
\end{abstract}

Kata kunci: aplikasi, dosis, gulma, herbisida, IPA glifosat

\section{PENDAHULUAN}

Karet (Hevea brasiliensis Muel. Arg.) merupakan salah satu tanaman yang termasuk ke dalam tanaman perkebunan yang hasil olahan getahnya banyak dimanfaatkan pada alat transportasi. Indonesia merupakan negara yang memiliki kesempatan besar dalam industri karet, baik secara kualitas maupun kuantitas. Menurut Kementrian Pertanian (2012), pada tahun 2011 luas areal perkebunan karet Indonesia mencapai 3.4 juta hektar dan produksi karet 2.8 juta ton. 
Data ini menunjukan adanya peningkatan produktivitas dari tahun 2010, yaitu 2.41 juta ton.

Meningkatkan produksi hasil perkebunan sering kali ditemui berbagai kendala, diantaranya semakin berkurangnya ketersediaan tenaga kerja yang berdampak pada peningkatan permintaan upah terutama pada saat pengolahan tanah. Kegiatan penting lainnya adalah melakukan pengendalian gulma yang tumbuh di sekitar tajuk tanaman. Gulma yang tumbuh bersama-sama dengan tanaman karet diketahui dapat menyebabkan kerugian terhadap karet tersebut akibat adanya kompetisi antara tanaman dengan gulma dalam memanfaatkan sarana tumbuh seperti air, unsur hara, cahaya matahari dan ruang tumbuh. Menurut Wiroatmodjo at al. (1992) gulma atau tanaman yang tidak diinginkan keberadaannya menjadi pesaing utama tanaman utama pada saat pertumbuhan tanaman.

Herbisida merupakan bahan kimia yang dapat menghentikan pertumbuhan gulma sementara atau seterusnya bila diperlakukan pada ukuran yang tepat (Sembodo 2010). Pemilihan herbisida yang sesuai untuk pengendalian gulma di pertanaman karet merupakan suatu hal yang sangat penting. Pemilihan dilakukan dengan memperhatikan daya efikasi herbisida terhadap gulma dan ada tidaknya fitotoksisitas pada tanaman. Pengendalian gulma memakai herbisida diperoleh hasil yang cukup memuaskan, namun penggunaan herbisida juga dapat menyebabkan perubahan komposisi spesies dan kepadatan (density) gulma disuatu tempat dalam jangka waktu lama. Salah satu bahan aktif herbisida yang sering digunkan dalam pengendalian gulma di perkebunan karet adalah IPA glifosat.

Menurut Katritzky et al. (2002) Indole-3propionic acid (IPA) adalah hormon tanaman endogen dan konjugasi asam aminonya diketahui untuk berinteraksi dengan albumin serum. Nufarm (2012) menambahkan IPA glifosat merupakan herbisida purna tumbuh yang diformulasi dalam bentuk larutan yang mudah larut dalam air yang dapat mengendalikan gulma berdaun sempit, berdaun lebar, dan teki-tekian serta mempunyai spektrum yang luas dan termasuk herbisida yang bersifat selektif. Oleh karena itu, penelitian ini dilaksanakan untuk mengetahui efektivitas dan efek toksisitasnya untuk menekan pertumbuhan gulma pada tanaman karet belum menghasilkan.

\section{BAHAN DAN METODE}

Penelitian ini dilaksankan di perkebunan karet (TBM) PTP Nusantara VIII (Persero)
Cikumpay, Kabupaten Purwakarta, Jawa Barat dan di Laboratorium Pasca Panen, Departemaen Agronomi dan Hortikultura, Fakultas Pertanian, Institut Pertanian Bogor. Penelitian berlangsung selama empat bulan dari bulan September 2012 sampai bulan Desember 2012.

Kultivar yang digunakan adalah semua klon/jenis karet PR 255 dengan umur yang seragam 4 tahun. Herbisida yang digunakan adalah herbisida yang diuji yaitu herbisida IPA glifosat 486 SL serta 15 iter air. Alat yang dipakai dalam penelitian ini adalah sprayer knapsack semi otomatis dan nozel T-jet warna biru, gelas ukur, ember, timbangan, tali, label, plastik, amplop, pisau cuter, spidol, kamera digital, oven dan kuadran dengan ukuran $0.5 \mathrm{~m}$ x $0.5 \mathrm{~m}$.

Penelitian ini menggunkan rancangan kelompok lengkap teracak (RKLT) dengan satu faktor yang terdiri dari tujuh perlakuan dengan empat kali ulangan pada setiap herbisida yang diuji. Perlakuan menggunakan herbisida dengan dosis $1.0 \mathrm{l} / \mathrm{ha}, 1.5 \mathrm{l} / \mathrm{ha}, 2.0 \mathrm{l} / \mathrm{ha}$, dosis $2.5 \mathrm{l} / \mathrm{ha}$ dan $3.0 \mathrm{l} / \mathrm{ha}$. Perlakuan keenam tidak menggunakan herbisida tetapi dengan cara penyiangan manual dengan teknik babat dempes, yang akan dilakukan sekali pada pengamatan 10 minggu setelah aplikasi (12 MST). Perlakuan ketujuh merupakan kontrol yang digunakan sebagai pembanding yang tidak diberikan penyiangan dan perlakuan apapun. Model rancangan yang digunakan adalah:

$\mathrm{Y}_{i j}=\mu+\tau_{i}+\beta_{j}+\varepsilon_{i j}$

Keterangan:

$\mathrm{Y}_{i j}=$ pengamatan pada perlakuan ke-i dan kelompok ke-j

$\mu=$ nilai rata-rata populasi

$\tau_{i}=$ pengaruh aditif dari perlakuan ke- $\mathrm{i}$

$\beta_{j}=$ pengaruh aditif dari kelompok ke-j

$\varepsilon_{i j}=$ pengaruh acak dari perlakuan ke-i dan kelompok ke-j

Pengolahan data dikerjakan menggunakan metode analisis ragam. Apabila perlakuan menunjukkan pengaruh nyata maka akan dulakukan uji lanjut Duncan Multiple Range Test (DMRT) terhadap perbedaan nilai rata-rata pada taraf kepercayaan 5\% dengan prosedur uji yang sesuai dengan rancangan percobaan (Gomez dan Gomes 1995). Satuan petak terdiri atas gulma dibawah 5 tanaman karet (TBM) atau dengan luas $3 \mathrm{~m} \times 15 \mathrm{~m}$. Jarak antar satuan petak perlakuan adalah satu tanaman karet di dalam barisan.

Analisis vegetasi dilakukan terlebih dahulu sebelum melakukan aplikasi herbisida untuk mengetahui jenis gulma yang dominan. 
Analisis vegetasi dilakukan dengan menggunakan alat kuadran yang berukuran $0.5 \mathrm{~m}$ x $0.5 \mathrm{~m}$ dengan cara mengambil contoh gulma secara sistematis pada areal percobaan yang terlebih dahulu telah dilakukan pembagian petak percobaan yang disesuaikan berdasarkan perlakuan yang akan diberikan dengan jumlah 28 petak percobaan. Setiap petak berukuran $3 \mathrm{~m}$ x $15 \mathrm{~m}$ dengan jarak antar ulangan adalah $3 \mathrm{~m}$ dan jarak antara petak dalam satu ulangan adalah $2 \mathrm{~m}$. Keadaan tumbuhan karet relatif seragam dengan jarak tanam sesuai dengan kondisi perkebunan setempat yaitu $2.5 \mathrm{~m} \mathrm{x} 6 \mathrm{~m}$ dengan jumlah populasi perhektar adalah 667 pohon. Pemeliharaan tanaman karet terpelihara dengan baik sesuai dengan anjuran perkebunan setempat. Penutupan gulma secara umum tidak kurang dari $75 \%$ dengan kondisi lingkungan yang mendukung.

Cara aplikasi herbisida dan alat yang digunakan disesuaikan dengan sifat fisik, cara kerja dan bentuk formulasi herbisida yang diuji. Untuk formulasi yang larut dalam air, digunakan alat semprot punggung semi otomatis (semi automatic sprayer) dan nozel T-jet dengan tekanan $1 \mathrm{~kg} / \mathrm{cm}^{2}(15-20 \mathrm{psi})$.

Data contoh biomasa gulma pada setiap satuan petak perlakuan. Diamati sebanyak dua petak kuadrat, menggunakan metode kuadrat berukuran $0.5 \times 0.5 \mathrm{~m}$. Letak petak kuadrat ditetapkan secara sistematis. Waktu pengambilan contoh gulma dilakukan sebelum dan setelah aplikasi. Pengambilan contoh gulma sebelum aplikasi digunakan untuk data biomasa kerapatan dan frekwensi dilakukan sebelum aplikasi dimaksudkan untuk menganalisis vegetasi menggunakan tehnik sum dominance ratio (SDR), yaitu proses perhitungan jumlah dominasi gulma yang ada di areal percobaan tersebut. Pengambilan contoh setelah aplikasi dilakukan setiap 2 minggu sekali setelah aplikasi, yaitu pada 2, 4, 6, 8, 10 dan 12 MSA.
Contoh gulma yang diambil adalah gulma sasaran yang menjadi target herbisida yang diuji yang diperoleh menggunakan teknik pelemparan alat kuadran perpetak perlakuan. Gulma yang masih segar dipotong tepat setinggi permukaan tanah, kemudian dipisahkan setiap spesies. Selanjutnya gulma dikeringkan pada oven dengan temperatur $80^{\circ} \mathrm{C}$ selama 48 , lalu ditimbang.

Jumlah contoh tanaman karet untuk pengamatan fitotoksisitas adalah sebanyak 3 tanaman dalam satuan petak perlakuan dan ditentukan secara acak. Tingkat keracunan dinilai secara visual terhadap populasi kultivar dalam satuan petak perlakuan, diamati pada 2, 4 dan 6 minggu setelah aplikasi atau setelah aplikasi kedua. Skoring keracunan sebagai berikut: $0=$ tidak ada keracunan, 0 - 5\% bentuk warna daun dan atau pertumbuhan tanaman karet tidak normal, $1=$ keracunan ringan, $>5-20 \%$ bentuk warna daun dan atau pertumbuhan tanaman karet tidak normal, 2 = keracunan sedang, $>20-5 \%$ bentuk warna daun dan atau pertumbuhan tanaman karet tidak normal, $3=$ keracunan berat, $>50-75 \%$ bentuk warna daun dan atau pertumbuhan tanaman karet tidak normal, $4=$ keracunan sangat berat, $>75 \%$ bentuk warna daun dan atau pertumbuhan tanaman karet tidak normal

\section{HASIL DAN PEMBAHASAN}

\section{Gulma Dominan}

Hasil analisis vegetasi gulma sebelum aplikasi herbisida IPA glifosat 486 sl disajikan pada Tabel 1. Berdasarkan hasil analisis vegetasi sebelum aplikasi herbisida, diperoleh empat gulma dominan yaitu Paspalum conjugatum, Tetracera indica, Ficus septica, dan Eleusin indica. Adapun spesies gulma lain seblum aplikasi herbisida yang cukup banyak tumbuh di areal penelitian yaitu Ottoclhoa nodosa, Cynodon dactylon, dan Chromolona odorata.

Tabel 1. Nisbah jumlah dominansi (NJD) gulma sebelum aplikasi herbisida

\begin{tabular}{clcr}
\hline Nomor & \multicolumn{1}{c}{ Spesies gulma } & Gulma jenis & NJD (\%) \\
\hline 1 & Paspalum conjugatum & rumput & 17.72 \\
2 & Tetracera indica & daun lebar & 13.90 \\
3 & Ficus septic & daun lebar & 9.02 \\
4 & Eleusin indica & rumput & 7.73 \\
5 & Gulma lain & campuran & 51.63 \\
\hline
\end{tabular}

Analisis vegetasi juga dilakukan pada akhir percobaan untuk mengetahui apakah ada perubahan dari jumlah gulma yang dominan ketika sebelum aplikasi dengan setelah aplikasi herbisida. Hasil analisis vegetasi akhir yang dilakukan pada lahan percobaan memberikan gambaran umum 
tentang dominansi gulma setelah aplikasi herbisida. Tabel 2 menunjukan bahwa terjadi perubahan dominansi gulma yang terjadi pada akhir percobaan setelah aplikasi herbisida dibandingakan dengan sebelum aplikasi herbisida.

Dominansi gulma yang paling tinggi pada akhir percobaan yaitu gulma dari spesies Borreria alata dan Cyrtococcum patens, dengan persentase masing-masing mencapai $23.42 \%$ untuk Borreria alata dan $23.38 \%$ untuk Cyrtococcum patens (Tabel 2). Data pada Tabel 2 menunjukan bahwa gulma dari golongan daun lebar (Borreria alata) lebih dominan dari pada gulma dari golongan rumput. Berbeda halnya dengan hasil analisis vegetasi sebelum aplikasi terlihat bahwa gulma dari golongan rumput (Paspalum conjugatum) yang lebih dominan. Secara keseluruhan terjadi perubahan dominansi gulma secara signifikan antara sebelum aplikasi herbisida (Tabel 1) dengan dominansi gulma setelah aplikasi herbisida (Tabel 2).

Tabel 2. Nisbah jumlah dominansi (NJD) gulma setelah aplikasi herbisida

\begin{tabular}{clcr}
\hline Nomor & \multicolumn{1}{c}{ Jenis gulma } & Gulma jenis & NJD (\%) \\
\hline 1 & Borreria alata & daun lebar & 23.42 \\
2 & Cyrtococcum patens & rumput & 23.38 \\
3 & Mikania micrantha & daun lebar & 14.24 \\
4 & Tetracera indica & daun lebar & 16.47 \\
5 & Gulma lain & campuran & 22.49 \\
\hline
\end{tabular}

Terjadinya perubahan dominansi yang signifikan menunjukan bahwa herbisida IPA Glifosal 486 SL yang memiliki bahan aktif glifosat efektif untuk mengendalikan gulma dari golongan rumput maupun daun lebar. Namun, herbisida IPA glifosat 486 SL kurang efektif untuk mengendalikan gulma Tetracera indica. Hal ini terjadi disebabkan oleh beberapa faktor diantaranya, adanya trikoma pada daun, tajuk tanaman yang kuat dan berkayu yang sulit ditembus harbisida sistemik (Barus 2003).

\section{Bobot Kering Gulma Total}

Bobot kering gulma total merupakan jumlah bobot kering gulma secara keseluruhan pada setiap petak perlakuan dan setiap ulangan. Perlakuan herbisida IPA glifosat 486 SL dengan beberapa dosis berpengaruh nyata pada 4 dan 12 MSA, sedangkan pada 2, 6, 8, dan 10 MSA berpengaruh tidak nyata. Perlakuan herbisida IPA glifosat $486 \mathrm{SL}$ dengan dosis $1.0 \mathrm{l} / \mathrm{ha}$ berbeda nyata dengan perlakuan manual pada 4 MSA dan dengan perlakuan kontrol pada 12 MSA. Hal ini dapat terjadi karena pada perlakuan dengan dosis $1.0 \mathrm{l} / \mathrm{ha}$ kuantitas gulma yang teranveg lebih banyak. Hal tersebut menyebabkan bobot kering gulma total dengan dosis $1.0 \mathrm{l} / \mathrm{ha}$ bobot kering totalnya cukup tinggi pada 4 dan 8 MSA. Bobot kering gulma total terendah terdapat pada perlakuan herbisida dengan perlakuan manual pada 12 MSA, yaitu 0.748 gram. Hal ini dapat terjadi karena pengendalian manual mulai dilakukan pada 10 MSA.

Pengendalian manual dilakukan mulai 10 MSA dikarenakan sebelum 10 MSA pertumbuhan gulma masih kecil dan belum ideal untuk dilakukan pembabatan. Bobot kering gulma total tertinggi terdapat pada perlakuan Kontrol pada pengamatan 4 MSA sebesar 22.973 gram. Sastroutomo (1990) menyatakan bahwa secara umum hampir semua biji gulma yang ada dalam tanah berkecambah dalam waktu yang relatif singkat (2 minggu). Rata-rata perkecambahan gulma dimulai setelah 2 minggu dan meningkat jumlahnya setelah 2 bulan (8 $\mathrm{MSA})$.

Tabel 3. Pengaruh perlakuan pengendalian gulma terhadap bobot kering gulma total

\begin{tabular}{|c|c|c|c|c|c|c|c|}
\hline \multirow[t]{2}{*}{ Perlakuan } & \multirow[t]{2}{*}{ Dosis } & \multicolumn{6}{|c|}{ Minggu setelah aplikasi (MSA) } \\
\hline & & 2 & 4 & 6 & 8 & 10 & 12 \\
\hline & . & $\ldots \ldots \ldots \ldots .(\mathrm{g} / \mathrm{C}$ & $\left.25 \mathrm{~m}^{2}\right)$. & $\ldots \ldots \ldots$ & 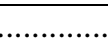 & & \\
\hline Kontrol & - & 8.615 & 22.973 a & 15.715 & 10.795 & 10.048 & $19.523 \mathrm{a}$ \\
\hline Manual & - & 11.008 & $7.303 \mathrm{~b}$ & 13.463 & 11.298 & 10.550 & $0.748 \mathrm{~b}$ \\
\hline Glifosat $486 \mathrm{sl}$ & $1.0 \mathrm{l} / \mathrm{ha}$ & 7.480 & 22.935 a & 12.843 & 21.495 & 6.420 & $5.213 \mathrm{~b}$ \\
\hline Glifosat $486 \mathrm{sl}$ & $1.5 \mathrm{l} / \mathrm{ha}$ & 11.773 & $9.578 \mathrm{~b}$ & 10.940 & 10.175 & 7.445 & $4.683 \mathrm{~b}$ \\
\hline Glifosat $486 \mathrm{sl}$ & $2.0 \mathrm{l} / \mathrm{ha}$ & 14.413 & $7.948 \mathrm{~b}$ & 11.808 & 10.853 & 7.430 & $9.190 \mathrm{~b}$ \\
\hline
\end{tabular}




\begin{tabular}{lllrrrrr} 
Glifosat $486 \mathrm{sl}$ & $2.5 \mathrm{l} / \mathrm{ha}$ & 11.640 & $13.868 \mathrm{ab}$ & 17.610 & 21.760 & 15.713 & $5.918 \mathrm{~b}$ \\
Glifosat $486 \mathrm{sl}$ & $3.0 \mathrm{l} / \mathrm{ha}$ & 10.850 & $9.433 \mathrm{~b}$ & 15.530 & 21.400 & 7.965 & $9.543 \mathrm{~b}$ \\
\hline
\end{tabular}

${ }^{\text {a} A n g k a ~ p a d a ~ k o l o m ~ y a n g ~ s a m a ~ d a n ~ d i i k u t i ~ o l e h ~ h u r u f ~ y a n g ~ s a m a ~ t i d a k ~ b e r b e d a ~ n y a t a ~ p a d a ~ t a r a f ~} 5 \%$ uji duncan. Data diatas merupakan data hasil transformasi $\sqrt{ }(\mathrm{x}+4)$

Berdasarkan data tabel, secara umum perlakuan herbisida dengan dosis $1.01 \mathrm{ha}^{-1}$ lebih efektif dan efisien diaplikasikan dari segi biaya dan toksisitas bila dibandingkan dengan perlakuan dosis yang lainnya atau yang lebih tinggi. Karena diantara perlakuan herbisida dengan dosis 1.01 ha $^{-}$ 1 menunjukan hasil yang cukup baik dalam penurunan kuantitas berat kering gulma secara total. Selain itu, apabila perlakuan dosis $1.01 \mathrm{ha}^{-1}$ dibandingkan dengan perlakuan manual memang terlihat berbeda nyata, namun jika dibandingkan dengan faktor biaya HOK diantara keduanya, perlakuan akan dapat menutupi dan menggantikan perlakuan manual yang jauh lebih mahal. Sehingga diambil dosis yang paling rendah untuk efisiensi biaya.

\section{Bobot Kering Gulma Daun Lebar}

Gulma berdaun lebar cenderung untuk dapat menurunkan hasil panenan yang lebih besar jika dibandingkan dengan gulma rerumputan atau sejenisnya (Sastroutomo 1990). Analisis data Tabel 4 menunjukan bahwa secara keseluruhan aplikasi herbisisda IPA glifosat 486 SL pada gulma berdaun lebar memberikan pengaruh yang tidak berbeda nyata pada $2,4,6,8,10$ dan 12 MSA. Hal ini menerangkan bahwa setiap dosis

perlakuan herbisida yang diaplikasikan tidak efektif untuk mengendalikan gulma dari golongan daun lebar. Perbedaan yang nyata hanya terjadi pada perlakuan $8 \mathrm{MSA}$ dengan dosis $2.5 \mathrm{l} / \mathrm{ha}$ dan 3.0 1/ha terhadap perlakuan kontrol. Nilai bobot kering gulma daun lebar totol pada perlakuan 8 MSA dengan dosis 2.5 1/ha dan 3.0 1/ha adalah salah satu yang terendah mencapai 0.00 gram. Hal ini menunjukan bahwa kerja herbisida IPA glifosat 486 SL mulai terlihat pada $8 \mathrm{MSA}$. Selain itu, perlakuan dengan dosis 2.5 1/ha dan 3.0 1/ha sedikit lebih efektif dibandingakan dengan perlakuan dosis lain.

Bobot kering gulma daun lebar total terendah terdapat pada petak percobaan dengan aplikasi herbisida dengan dosis 1.0 1/ha pada 4 MSA, 2.5 1/ha dan 3.0 1/ha pada pengamatan 8 MSA, serta perlakuan kontrol pada pengamatan 6 dan 12 MSA. Bobot kering gulma daun lebar total tertinggi yaitu dengan dosis 1.5 1/ha pada pengamatan 2 MSA. Bobot kering rata-rata gulma daun lebar total tertinggi adalah 10.845 gram dan yang terendah adalah 0.248 gram. Secara keseluruhan nilai rata-rata bobot kering gulma daun lebar total pada setiap pengamatan mengalami fluktuasi data akibat sebaran gulma daun lebar yang tidak merata ada pada setiap petak percobaan.

Tabel 4. Pengaruh perlakuan pengendalian gulma terhadap bobot kering gulma daun lebar

\begin{tabular}{|c|c|c|c|c|c|c|c|}
\hline \multirow[t]{2}{*}{ Perlakuan } & \multirow[t]{2}{*}{ Dosis } & \multicolumn{6}{|c|}{ Minggu Setelah Aplikasi (MSA) } \\
\hline & & 2 & 4 & 6 & 8 & 10 & 12 \\
\hline & $\ldots \ldots$ & ............ & ............. & $0.25 \mathrm{~m}$ & . & 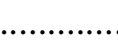 & \\
\hline Kontrol & - & 2.995 & 4.370 & 0.000 & 5.480 & 2.740 & 0.000 \\
\hline Manual & - & 7.863 & 1.235 & 5.155 & 1.850 & 5.015 & 0.640 \\
\hline Glifosat $486 \mathrm{sl}$ & $1.0 \mathrm{l} / \mathrm{ha}$ & 5.650 & 0.000 & 3.765 & 0.273 & 5.733 & 5.230 \\
\hline Glifosat $486 \mathrm{sl}$ & 1.5 1/ha & 10.845 & 0.285 & 5.168 & 1.278 & 3.320 & 5.518 \\
\hline Glifosat $486 \mathrm{sl}$ & 2.0 1/ha & 4.473 & 1.513 & 3.183 & 1.793 & 1.195 & 4.383 \\
\hline Glifosat $486 \mathrm{sl}$ & 2.5 l/ha & 7.250 & 7.250 & 4.305 & 0.000 & 2.335 & 1.405 \\
\hline Glifosat $486 \mathrm{sl}$ & 3.0 1/ha & 0.248 & 2.550 & 4.353 & 0.000 & 3.400 & 7.693 \\
\hline
\end{tabular}

${ }^{a}$ Angka pada kolom yang sama dan diikuti oleh huruf yang sama tidak berbeda nyata pada taraf $5 \%$ uji duncan. Data diatas merupakan data hasil transformasi $\sqrt{ }(x+4)$

Pada Tabel 4 dapat dilihat bahwa bobot kering gulma daun lebar total mulai mengalami peningkatan konstan pada 8 MSA pada setiap dosis perlakuan kecuali untuk perlakuan kontrol dan manual yang mengalami penurunan.
Peningkatan bobot kering tersebut terjadi dikarenakan terjadinya peningkatan intensitas curah hujan di areal percobaan. Sembodo (2010) menyatakan bahwa gulma dari spesies yang sama pun kadangkala memberikan respon yang berbeda 
terhadap herbisida tertentu. Apalagi antar jenis gulma walaupun dalam satu golongan tertentu, respon yang ditunjukkan sering berbeda. Fadhly dan Tabri (2004) menambahkan bahwa setiap golongan gulma memiliki respon yang berbeda atas penerimaan herbisida. Herbisida memiliki efektivitas yang beragam berdasarkan cara kerjanya.

\section{Bobot Kering Gulma Rumput}

Hampir semua jenis rerumputan adalah jenis $\mathrm{C} 4$, maka pengaruh kompetisinya jauh lebih besar jika dibandingkan dengan gulma berdaun lebar, dapat dijelaskan sebagai akibat dari pertumbuhannya yang menyebar luas dengan daun yang tumbuh horizontal yang membuatnya semakin kompetitif akan cahaya. Secara keseluruhan dari data Tabel 5 dapat dilihat bahwa aplikasi herbisida IPA glifosat 486 SL tidak memberikan pengaruh yang nyata dari mulai pengamatan 2 MSA hingga 10 MSA. Pengaruh yang nyata terlihat pada perlaukan dengan dosis $2.5 \mathrm{l} / \mathrm{ha}$ pada pengamatan $4 \mathrm{MSA}$ terhadap kontrol sedangkan pengaruh yang sangat nyata terlihat pada perlakuan kontrol terhadap semua perlakuan manual dan dosis lainnya.

Pengaruh perlakuan pengendalian gulma terhadap bobot kering gulma rumput total dapat dilihat pada Tabel 5. Pada pengamatan mulai dari 2 MSA hingga 4 MSA menunjukan kenaikan jumlah bobot kering gulma rumput yang begitu besar pada perlakuan kontrol. Perlakuan dengan dosis $1.0 \mathrm{l} / \mathrm{ha}, 2.5 \mathrm{l} / \mathrm{ha}$ dan 3.01/ha mengalami peningkatan bobot kering gulma rumput total pada pengamatan 2 MSA hingga 8 MSA. Namun, pada pengamatan 10 MSA dan 12 MSA mengalami penurunan bobot kering gulma rumput total. Analisis dari data Tabel 5 menunjukan bahwa secara keseluruhan bobot kering gulma rumput total pada setiap perlakuan seperti menunjukan pergerakan parabola mulai dari 2 MSA hingga 12 MSA, kecuali pada perlakuan kontrol yang mengalami kenaikan yang signifikan pada 12 MSA.

Terjadinya kenaikan bobot kering gulma rumput total yang signifikan pada perlakuan kontrol pada 12 MSA menunjukan bahwa adanya pengaruh tingginya intensitas curah hujan yang meningkatkan daya tumbuh gulma. Selain itu perlakuan kontrol yang tidak mendapatkan perlakuan apapun juga menyebabkan cepatnya pertumbuhkembangan gulma rumput. Terjadinya kenaikan bobot kering gulma rumput pada 2 MSA hingga 4 MSA kemudian mengalami penurunan secara konstan hingga pengamatan 12 MSA seperti pergerakan parabola menunjukan bahwa aplikasi herbisida IPA glifosat 486 SL cukup efektif untuk mengendalikan gulma rumput pada pertanaman karet belum menghasilkan.

Bobot kering gulma rumput total terendah terdapat pada perlakuan manual pada pengamatan 12 MSA atau pengamatan 2 minggu setelah pembabatan gulma dengan bobot sebesar 0.26 gram, dan bobot kering gulma rumput total tertinggi terdapat pada perlakuan kontrol pada pengamatan 4 MSA sebesar 24.39 gram. Berdasarkan data statistik, secara umum perlakuan herbisida dengan dosis rendah yaitu 1.5 1/ha merupakan yang paling efektif apabila dibandingkan dengan perlakuan lainnya. Selain itu, perbedaan bobot kering gulma total pada perlakuan dengan dosis $1.5 \mathrm{l} / \mathrm{ha}$ dengan perlakuan kontrol perbedaannya sangat terlihat. Bobot kering gulma rumput total perlakuan kontrol jauh lebih besar dari perlakuan dengan dosis 1.5 1/ha.

Tabel 5. Pengaruh perlakuan pengendalian gulma terhadap bobot kering gulma rumput

\begin{tabular}{|c|c|c|c|c|c|c|c|}
\hline \multirow[t]{2}{*}{ Perlakuan } & \multirow[t]{2}{*}{ Dosis } & \multicolumn{6}{|c|}{ Minggu setelah aplikasi (MSA) } \\
\hline & & 2 & 4 & 6 & 8 & 10 & 12 \\
\hline & & & $\ldots . .(\mathrm{g} /$ & $\left.n^{2}\right)$. & & & \\
\hline Kontrol & - & 11.118 & $24.390 \mathrm{a}$ & 15.715 & 7.238 & 7.308 & $19.523 \mathrm{a}$ \\
\hline Manual & 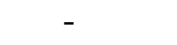 & 5.998 & $10.850 a b c$ & 10.988 & 9.490 & 10.323 & $0.370 \mathrm{~b}$ \\
\hline Glifosat $486 \mathrm{sl}$ & $1.0 \mathrm{l} / \mathrm{ha}$ & 4.058 & $22.935 \mathrm{ab}$ & 11.603 & 21.618 & 2.708 & $0.285 \mathrm{~b}$ \\
\hline Glifosat $486 \mathrm{sl}$ & $1.5 \mathrm{l} / \mathrm{ha}$ & 3.928 & $9.553 \mathrm{abc}$ & 7.625 & 8.898 & 7.993 & $1.768 \mathrm{~b}$ \\
\hline Glifosat $486 \mathrm{sl}$ & $2.0 \mathrm{l} / \mathrm{ha}$ & 9.940 & $8.540 \mathrm{bc}$ & 13.248 & 11.725 & 7.175 & $6.330 \mathrm{~b}$ \\
\hline Glifos & $2.5 \mathrm{l} / \mathrm{ha}$ & 9.273 & $60 \mathrm{c}$ & 18. & 21.760 & 13.378 & $5.533 \mathrm{~b}$ \\
\hline Glifosat $486 \mathrm{sl}$ & $3.0 \mathrm{l} / \mathrm{ha}$ & 6.230 & $8.850 \mathrm{abc}$ & 13.838 & 21.400 & 5.453 & $4.505 \mathrm{~b}$ \\
\hline
\end{tabular}

${ }^{a}$ Angka pada kolom yang sama dan diikuti oleh huruf yang sama tidak berbeda nyata pada taraf $5 \%$ uji duncan. Data diatas merupakan data hasil transformasi $\sqrt{ }(\mathrm{x}+4)$ 
Fitotoksisitas Pada Tanaman Karet Belum Menghasilkan

Salah satu pertimbangan yang penting dalam pemakaian herbisida adalah untuk mendapatkan pengendalian yang selektif, yaitu mematikan gulma, tetapi tidak merusak tanaman budidaya. Respon beberapa jenis tumbuhan yang berbeda pada satu jenis herbisida dengan dosis yang sama akan berbeda pula. Hal ini diakibatkan karena letak kegiatan herbisida itu pada masingmasing tumbuhan juga berbeda ataupun lama beradanya herbisida itu dalam tumbuhan yang berbeda (persistensi). Bagian tubuh tumbuhan di bawah dan diatas permukaan tanah diliputi suatu membran yang disebut dengan kutikula yang terdiri dari membran benda mati, non-seluler, dan lipoida yang merupakan penghalang utama masuknya herbisida (Moenandir 1990).

Pengamatan toksisitas herbisida IPA glifosat $486 \mathrm{SL}$ pada tanaman karet yang dilakukan secara visual tidak menunjukan adanya keracunan pada tanaman karet dari setiap perlakuan dosis herbisida, seperti terlihat pada Tabel 6 dan Gambar 1. Hal ini menunjukan bahwa tanaman karet mampu memetabolisme komponen komponen yang terdapat pada herbisida IPA glifosat 486 SL pada dosis perlakuan yang diberikan pada percobaan ini. Tanaman karet di lahan percobaan merupakan tanaman karet yang belum menghasilkan yang telah berumur 4 tahun. Pada umur 4 tahun kulit batang tanaman karet telah cukup tebal dan tajuk tanamannya juga tinggi, yaitu lebih dari 3 meter. Kulit tanaman yang tebal dapat menghalangi masuknya cairan glifosat ke dalam sistim jaringan simplas tanaman. Selain itu, Menurut Yakup (2002), menyatakan bahwa penghambatan atau pemacuan pertumbuhan suatu tumbuhan ditentukan oleh dosis/konsentrasi herbisida tersebut. Suatu herbisida pada dosis atau konsentrasi tertentu dapat bersifat selektif, tetapi bila dosis/konsentrasi dinaikan atau diturunkan berubah menjadi tidak selektif.

Tabel 6. Data nilai rata-rata tingkat skoring toksisitas pada tanaman karet belum menghasilkan

\begin{tabular}{lcccc}
\hline \multirow{2}{*}{ Perlakuan dosis } & \multicolumn{3}{c}{ Rata-rata tingkat skoring keracunan } & Rata-rata \\
\cline { 2 - 5 } & 2 MSA & 4 MSA & 6 MSA & 0 \\
$1.0 \mathrm{l} / \mathrm{ha}$ & 0 & 0 & 0 & 0 \\
$1.5 \mathrm{l} / \mathrm{ha}$ & 0 & 0 & 0 & 0 \\
$2.0 \mathrm{l} / \mathrm{ha}$ & 0 & 0 & 0 & 0 \\
$2.5 \mathrm{l} / \mathrm{ha}$ & 0 & 0 & 0 & 0 \\
$3.0 \mathrm{l} / \mathrm{ha}$ & 0 & 0 & 0 & \\
\hline
\end{tabular}
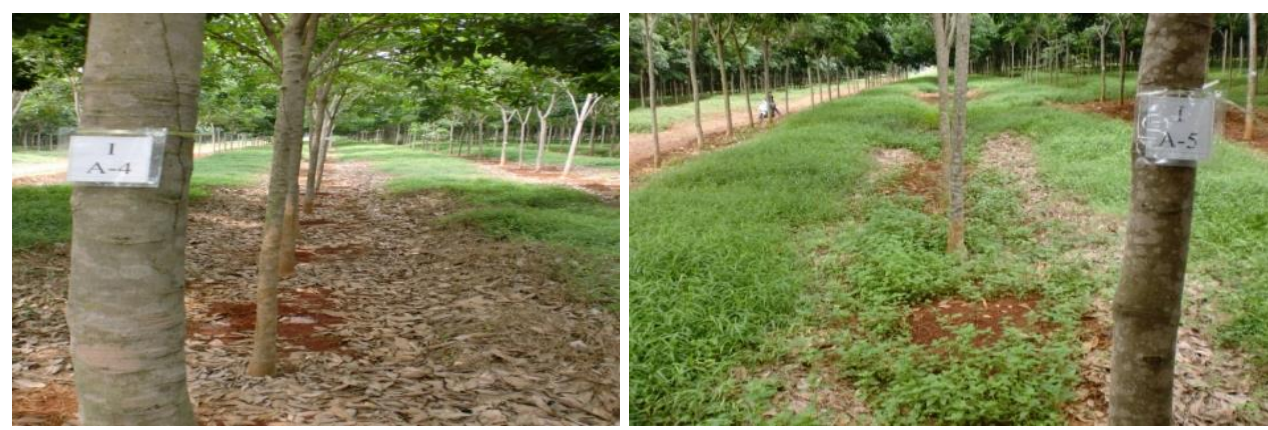

Gambar 1. Tidak terlihat adanya keracunan pada batang dan tajuk tanaman karet (4 MSA kiri), (10 MSA kanan)

\section{Perbandingan Dengan Pengendalian Mekanis}

Salah satu cara yang efektif dan efesien untuk meningkatkan pengendalian gulma pada areal pertanian adalah dengan mengkombinasikan herbisida dengan dosis rendah. Namun, dalam hal pengendalian gulma secara kimia perlu juga mempertimbangkan lingkungan yang pengendalian gulma 2004).

Adapun beberapa teknik pengendalian mekanis yang biasa dilakukan adalah dengan pengolahan tanah, penyiangan, pencabutan, 
pembabatan, pembakaran, dan penggenangan. Penyiangan manual yang dilakukan dalam percobaan ini membutuhkan waktu rata-rata 25 menit $/ 30 \mathrm{~m}^{2}$. Teknik yang digunakan adalah babat dempes, yang berarti bila dirata-ratakan untuk 1 ha membutuhkan waktu sekitar $139 \mathrm{jam} / \mathrm{ha}$ atau sekitar 20 HOK (1 HOK = 7 jam). Sedangkan untuk perlakuan herbisida menggunakan alat sprayer knapsack semi otomatis dengan nozel Tjet, yang menggunakan volume somprot 400 1/ha, dan memiliki nozel output sebesar $0.8 \mathrm{l} /$ menit, memerlukan waktu penyemprotan rata - rata 5 menit/30 $\mathrm{m}^{2}$ atau sekitar $28 \mathrm{jam} / \mathrm{ha}$ (4 HOK).

Pengendalian secara mekanis selain memerlukan waktu yang lebih lama dibandingkan dengan pengendalian secara kimia, juga memerlukan tenaga kerja yang banyak dan biaya yang lebih besar untuk membayar tenaga kerja tersebut. PTPN VIII Cikumpay memiliki standar upah untuk karyawan harian lepas yaitu rata-rata Rp 60 000/HOK. Sedangkan untuk harga herbisida IPA glifosat 486 SL yang diujikan dalam percobaan ini diperkirakan mempunyai harga jual sekitar Rp 100 000/liter. Perbandingan biaya yang dikeluarkan antara perlakuan penyiangan manual dengan perlakuan herbisida ditunjukan pada Tabel 7.

Perbandingan tingkat kemampuan untuk menekan pertumbuhan gulma antara perlakuan penyiangan manual dengan perlakuan herbisida juga menunjukan bahwa perlakuan herbisida atau pengendalian secara kimia memiliki hasil yang lebih baik untuk menekan pertumbuhan gulma dibandingkan dengan perlakuan penyiangan manual atau secara mekanis. Terlihat pada pengamatan 12 MSA setelah dilakukannya penyiangan manual pada 10 MSA, menunjukan bahwa perlakuan penyiangan manual memiliki nilai bobot kering gulma yang tidak jauh berbeda dibandingkan perlakuan herbisida pada semua dosis yang diujikan. Namun, dari segi biaya perlakuan manual terlihat jauh lebih tinggi dibandingkan dengan pelakuan dosis lainnya. Oleh sebab itu, walaupun perlakuan manual terlihat lebih efektif dibandingankan perlakuan manual dalam hal data bobot kering. Tetapi dalam segi biaya, perlakuan dosis sudah dapat menggantikan perlakuan manual karena lebih murah.

Berdasarkan perhitungan statistik, secara umum perlakuan herbisida dengan dosis $1.5 \mathrm{l} / \mathrm{ha}$ lebih efektif dan efisien diaplikasikan dari segi biaya dan toksisitas bila dibandingkan dengan perlakuan dosis yang lainnya atau yang lebih tinggi. Sehingga sudah dapat menggantikan perlakuan pengendalian manual dalam hal mengendalikan gulma karena lebih cepat dan murah.

Tabel 7. Perbandingan biaya antara perlakuan penyiangan manual dengan perlakuan herbisida pada beberapa dosis

\begin{tabular}{lcccr}
\hline Perlakuan & Jumlah HOK & Upah KHL (Rp) & Biaya herbisida (Rp) & Biaya total (Rp) \\
\hline Penyiangan manual & 20 & $60000 / \mathrm{HOK}$ & - & 1200000 \\
Dosis 1.0 1/ha & 4 & $60000 / \mathrm{HOK}$ & 100000 & 340000 \\
Dosis 1.5 1/ha & 4 & $60000 / \mathrm{HOK}$ & 150000 & 390000 \\
Dosis 2.0 1/ha & 4 & $60000 / \mathrm{HOK}$ & 200000 & 440000 \\
Dosis 2.5 1/ha & 4 & $60000 / \mathrm{HOK}$ & 250000 & 490000 \\
Dosis 3.0 1/ha & 4 & $60000 / \mathrm{HOK}$ & 300000 & 540000 \\
\hline
\end{tabular}

${ }^{\mathrm{a} H O K}$ : Hari Orang Kerja, KHL

\section{KESIMPULAN}

Secara umum berdasarkan hasil analisis statistik, rata-rata diantara perlakuan herbisida dengan dosis $1.01 \mathrm{ha}^{-1}, 2.01 \mathrm{ha}^{-1}, 2.51 \mathrm{ha}^{-1}$, dan 3.0 $1 \mathrm{ha}^{-1}$ tidak efektif pada pengendalian gulma di perkebunan karet belum mengasilkan yang telah berumur 4 tahun. Namun, dari segi biaya perlakuan dosis 1.0 - $3.01 \mathrm{ha}^{-1}$ yang lebih murah sudah dapat menggantikan perlakuan manual yang menghabiskan biaya lebih tinggi. Selama percobaan tidak ditemukan gejala keracunan pada perlakuan dosis 1.0 - $3.01 \mathrm{ha}^{-1}$, yang menunjukkan bahwa dosis herbisida yang diaplikasikan tidak membahayakan pertumbuhan tanaman karet.

\section{DAFTAR PUSTAKA}

Barus, E. 2003. Pengendalian Gulma di Perkebunan. Yogyakarta (ID): Penerbit Kanisius.103 hal.

Deptan. 2012. Luas areal dan produksi perkebunan seluruh Indonesia menurut pengusahaan. 
[Internet]. Tersedia pada: http://www. ditjenbun.deptan.go.id. [26 September 2012].

Fadhly, Tabri. 2004. Pengendalian Gulma pada Pertanaman Jagung. Pusat dan Pengembangan Tanaman Pangan (ID): Vol 12: 243.

Gomez, K.A., Gomez A.A. 1995. Prosedur Statistik Untuk Penelitian Pertanian. Sjamsudin E., Baharsjah J.S., penerjemah. Jakarata (ID): UI Pr. Terjemahan dari: Statistical Procedures for Agricultural Research.

Johnson, G.A., Hoverstad T.R., Greenwald R.E. 1998. Integrated weed management using corn spacing, herbicides, and cultivation. Agronomy Journal (US): Vol 90 (2): 4046.

Katritzky, A.R., Khelashvili L., Munawar M.A. 2002. Syntheses of IAA - and IPA Amino Acid Conjugates. Florida (USA): Departement of Chemistry, University of Florida.

Kurniawan, W., Abdullah L., Setiana M.A. 2007. Produksi dan kualitas rumut Brachiaria humidicola (Rend.) Sch, Digitaria decumbens Stent dan Stenotaphrum (Walter) O.Kunt. di bawah naungan sengon, karet dan kelapa sawit. Media Petern. 30(1):11-17.

Mulyati, S. 2004. Studi efektivitas herbisida glifosat $48 \%$ dan herbisida glifosat $24 \%+$ 2,4-D $12 \%$ untuk mengendalikan gulma pada tanaman kelapa sawit (Elaeis guineensis Jacq.) belum menghasilkan. [skripsi]. Bogor (ID): Departemen Budidaya Pertanian, Fakultas Pertanian, Institut Pertanian.

Nufarm. 2012. Bahan aktif IPA glifosat. [Internet]. [diunduhh 2012 Nov 6]. Tersedia pada: http://www.nufarm.com/ID/Supra615SL.

Sembodo, D.R.J. 2010. Gulma dan pengelolaanya. Yogyakarta (ID): Graha Ilmu. $166 \mathrm{hlm}$.

Wiroatmodjo, J., Utomo I.H., Lontoh A.P., Adams Y.M., Martha B.. 1992. Pengaruh pupuk kandang terhadap pertumbuhan dan hasil jahe (Zingiber officinale Rosc.) jenis badak serta periode kritis jahe terhadap kompetisi gulma. Bull. Agro: 20(3):1-9

Yakup. 2002. Gulma dan Teknik Pengendaliannya. Jakarta (ID): PT. Raja Grafindo Persada. 123 hal. 